\title{
Mídia e opinião pública: estudo de caso sobre o mensalão nas ópticas dos jornais Folha de S. Paulo e o Estado de S. Paulo
}

\author{
Media and public opinion: a case study on the \\ monthly allowance in optical newspaper Folha \\ de S. Paulo and Estado de S. Paulo
}

Sussane Martins ${ }^{1}$

1 Graduada em Comunicação Social - Jornalismo pelo Centro Universitário de Brasília UniCEUB. Atualmente, Assessora de Comunicação na Ordem dos Advogados do Brasil Seccional Distrito Federal (OAB/DF). E-mail: sussanem1@gmail.com.

\section{Resumo}

Este estudo tem por objetivo refletir sobre a influência da mídia e o seu papel no processo de formação da Opinião Pública, analisar, por meio de referenciais teóricos, a existência ou não da Opinião Pública. Realizar um estudo de caso para demonstração empírica dos processos de construção da Opinião Pública com base em conceitos-chaves: Mídia e Opinião Pública, que inicialmente são apresentados. A metodologia adotada pautou-se por uma revisão bibliográfica e pesquisa documental dos principais temas e autores relacionados. Apresenta-se estudo de caso a partir da observação e análise do chamado julgamento do "mensalão", visando compreender a relação entre as decisões do STF (Supremo Tribunal Federal) e a Opinião Pública. Com isso afirma-se a onipresença da mídia na vida dos cidadãos contemporâneos e sua contribuição na construção da Opinião Pública por meio das novas modalidades de comunicação digitais que pautam a mídia (agenda-setting)..

Palavras-chave: Mídia. Opinião pública. Mensalão. Agenda-setting.

\begin{abstract}
This study aims to reflect on the influence of the media and its central role in the formation of public opinion, analyzing through theoretical existence or not of public opinion. Conduct a case study to demonstrate empirically the processes of construction of public opinion based on key concepts: Media and Public Opinion, which are initially presented. The methodology was based on a literature review and desk research of the main themes and related authors. It presents a case study from the observation and analysis of the trial called "monthly allowance", to understand the relationship between the decisions of the Supreme Court (Supreme Court) and the public. With this we reaffirm the omnipresence of media in contemporary life of citizens and their contribution in building public opinion through new forms of digital communication that guide the media (agenda-setting). Because it is a review article, the study analyzes and discusses studies published.
\end{abstract}

Keywords: Media. Public opinion. Mensalão. Agenda-setting. 


\section{Introdução}

O objeto principal da pesquisa é "A influência da mídia e o seu papel na formação da Opinião Pública" e seus objetivos específicos são: compreender a mídia e seu papel no processo de formação da opinião pública. Analisar por meio de referenciais teóricos a existência ou não da opinião pública. Realizar um estudo de caso para demonstração empírica dos processos de construção da opinião pública.

O estudo foi feito a partir dos tópicos em discussão: Mídia e Opinião Pública. E, para elucidar a relação entre os conceitos, aplicou-se o método de estudo de caso _ análise de conteúdo jornalístico sobre o Caso Mensalão. Analisaram-se as matérias divulgadas pelos jornais impressos Folha de S. Paulo e O Estado de S. Paulo, no período de 20 a 24/08/2007. E, a partir dos resultados e discussões obtidos, permitiu-se uma nova perspectiva a respeito do tema Opinião Pública.

Os procedimentos metodológicos utilizados foram: o Método do Estudo de Caso para descobrir respostas indutivas a partir de elementos encontrados nas pesquisas, demonstração empírica dos processos de construção da Opinião Pública, com base nos conceitos levantados (Mídia x Opinião Pública), Revisão Bibliográfica e pesquisa documental dos principais temas e autores relacionados. Esse estudo fez uso do método da revisão e levantamento bibliográfico bem como da pesquisa documental. De forma direta, para análise e discussão o procedimento adotado para o referente artigo, adotou-se pesquisa bibliográfica que consistiu em reunir e selecionar os documentos pertinentes ao tema. A técnica foi escolhida por utilizar-se de dados empíricos.

$\mathrm{O}$ artigo encontra-se assim dividido: inicialmente é exposto a parte introdutória sobre os objetivos e breve síntese dos procedimentos metodológicos presentes no artigo, posteriormente passa-se a discussão dos conceitos (Mídia e Opinião Pública, Enquadramento, agenda-setting e crítica da mídia) na visão de autores tais como: Silverstone, Sartori, Duarte, Wolf, McLuhan, Lippmann dentre outros. E, nas considerações finais, o artigo encontrou o seu desfecho, com a análise do conteúdo jornalístico e os resultados obtidos por meio do método quantitativo.

A questão é: até que ponto a mídia contribui para a formação da Opinião Pública? O seu papel é de instrumento manipulador para manter sob controle o pensamento? Afinal, a Opinião Pública ainda existe ou a mídia tornou-se a Opinião Pública? A discussão a ser enfrentada neste estudo, que é o problema de pesquisa, é a onipresença da mídia na vida dos cidadãos contemporâneos e seu papel na construção da Opinião Pública.

Se o emissor tinha poder maior na mídia tradicional, hoje o "receptor" tem papel polar, pois representa a camada que repele, replica ou redireciona o conteúdo veiculado. Mas, ainda assim, a discussão pública continua a ocorrer. O que é admitido pela grande maioria de uma sociedade, as percepções políticas, a defesa ou rechaço de algum tema em debate, sendo esse assunto de interesse geral, é denominado de Opinião Pública.

\section{Mídia e a (de)formação da notícia}

O conceito de mídia, em comunicação, é empregado por se tratar de canais ou ferramentas usadas para armazenamento e transmissão de informações ou dados. Sinônimo dos meios de comunicação de massa ou agência de notícias, a mídia também se refere a um exclusivo meio utilizado para comunicar dados para qualquer finalidade.

A mídia tem o poder de estabelecer uma relação entre o emissor-receptor, de modo que essa relação não possa acontecer diretamente. Para o senso comum, a mídia só faz sentido se referida ao jornalismo ou a novas práticas de comunicação que impliquem transmissão de informações. Entretanto, a atuação da mídia não se limita apenas a essa área. Ela se faz presente como mediadora em diversos interesses.

Em relação ao jornalismo, a importância da mídia está no fato de ela ser o meio de propagação do trabalho jornalístico. Seria impossível obter informação e não ter um canal (meio) para que a notícia pudesse ser propagada. Apesar de ser utilizada em larga escala, encontrar uma definição consensual do conceito de mídia pelos pesquisadores do campo da comunicação é bem difícil pelo fato de existirem diversos conceitos e definições sobre esse tema.

A origem do uso da palavra mídia é encontrada em pesquisas norte-americanas sobre mass media, herdeiras (em sentido cronológico) dos estados sobre voto, comportamento eleitoral, propaganda e Opinião Pública nos períodos pré e pós-guerra entre os anos 1920 e 1940, nos Estados Unidos (WOLF, 2003). O mass media mais antigo, no entanto, é a imprensa. A presença de pouquíssimas imagens e muitas palavras à torna menos apelativa, entretanto, não deixa de influenciar a Opinião Pública. 
Além do significado original da palavra mídia (objeto de estudo do presente artigo) compreendido como meios de comunicação de massa (imprensa, televisão, rádio, internet, telefone, teatro, cinema, dança etc.) trata-se da adoção, da pronúncia inglesa para a palavra latina "media" retirada da expressão já citada acima mass media.

Vale ressaltar também que a área Comunicacional, nos últimos 50 anos tem sofrido diversas transformações por meio das novas tecnologias de comunicação, isto é, as tecnologias da mídia sofreram e sofrem modificações diariamente alterando a naturalidade do processo tradicional da Comunicação. A revolução digital é a principal causadora desses novos avanços tecnológicos que o Jornalismo tem vivido.

Segundo Lima (2004, p. 26), a distinção entre a nova e a velha mídia é nítida. Para ele, a velha mídia é caracterizada pela imprensa, cinema, rádio e televisão aberta. Já a nova mídia distingue-se da velha por estar significativamente à frente de seus interesses, "inclui os computadores multimídia, CD-ROM, os aparelhos de FAX de última geração, bancos de dados portáteis, livros eletrônicos, redes de vídeo, textos, telefones inteligentes e satélites de transmissão direta de TV para as residências". (DIZARD, 1998 apud LIMA, 2004) O papel da mídia é divulgar informação e conseguir mantê-la. Contudo, a mídia costuma distorcer os dados e descrevê-los de forma incompleta. "Na sociedade contemporânea, a mídia constitui um dos fatores fundamentais na formação do que é comumente conhecido como Opinião Pública" (RAYMUNDO, 2010).

Na nova mídia, cabe a cada um, portanto, exercitar a sua opinião de forma crítica sobre determinados assuntos, filtrando, questionando, apurando e principalmente checando os dados e as informações. O público tende a receber determinadas quantidades de subsídios e simplesmente torná-los unicamente como descrição fiel e fidedigno da realidade apresentada.

A mídia funciona como uma grande empresa e toda grande empresa visa ao lucro. O papel do jornalismo em sua essência é produzir e transmitir informação. Conteúdo de relevância e de interesse público. O poder da mídia é tamanho que a estudamos porque nos preocupamos com o seu poder. Temos a necessidade de compreender o quão poderosa ela é na vida cotidiana e na estruturação da experiência. A mídia pode destruir, influenciar, mudar, capacitar, animar, enganar, criar e sustentar sig- nificados, persuadir, reforçar, apresentar, revelar, explicar, seduzir, julgar, escutar, incitar, falar e ouvir.

Marshall McLuhan (apud SILVERSTONE, 2002, p. 20) enxerga na mídia um instrumento de condução e representação no cotidiano, ela é uma extensão do ser humano em todas as suas dimensões e experiências.

É no mundo mundano que a mídia opera de maneira mais significativa. Ela filtra e molda realidades cotidianas, por meio de suas representações singulares e múltiplas, fornecendo critérios, referências para a condução da vida diária, para a produção e a manutenção do senso comum.

\section{Enquadramento, agenda-setting e crítica da mídia}

A mídia exerce um papel de forte influência na vida e no cotidiano das pessoas. É um elemento importante na organização da esfera pública e deve ser encarada como elemento onipresente na ação, exposição e mediação, além de operar e dar visibilidade nos processos em comunicação.

Roger Silverstone (2002, p. 35), no segundo capítulo do livro Porque estudar a mídia? Mediação explica a dificuldade de quem trabalha na mídia ou com a mídia de discutir sobre ela sem se envolver. O sujeito deve ser o mais imparcial possível ao criticar a mídia (imprensa) e como ela incide nas questões importantes da sociedade. $\mathrm{O}$ autor diz que, segundo George Steiner, a mediação é como a tradução: não é completa, está sempre se transformando e talvez não seja inteiramente satisfatória. Afirma que a tradução é um ato de amor e envolve a confiança (pois no seu processo identificamos valor no texto de que estamos tratando), agressão (todos os atos de compreensão são violentos), apropriação (levamos os significados dos textos para casa) e a restituição (a reavaliação _ devolução de significado e até acréscimos de significados). Na tradução, entramos em um texto e afirmamos ter a posse do seu significado, mas segundo Luís Borges em Pierre Menard, nenhuma tradução é perfeita. Assim como a mediação.

A mídia não deve ser somente vista como importante e sim protagonista para todo e qualquer processo político e democrático da modernidade. A função da mídia, conhecida como o quarto poder é de participar, divulgar e obter transparência e compromisso com a verdade naquilo que se propõe na composição da informação. A sociedade tem a função de pautar a mídia para que seus processos sociais sejam respondidos e a mídia, por sua vez visa atribuir visibilidade a esses processos. 
O enquadramento noticioso ou framing (social sciences) é muito usado pela mídia quando se deseja modelar, ocultar, destacar e enfatizar algo, ou seja, dar enfoque utilizando certas expressões, palavras e adjetivos. $\mathrm{O}$ enquadramento permite que o interlocutor possa compreender de forma recortada uma informação. Contudo, espera-se que haja, no mínimo, certo cuidado com aquilo que é transmitido até porque os veículos seguem uma linha editorial.

Segundo Rothberg (2010, p. 54), o conceito de enquadramento é facilmente entendido e abordado pelo seguinte:

Porto (2004, p. 78) caracteriza os enquadramentos como "marcos interpretativos mais gerais construídos socialmente que permitem as pessoas fazer sentido dos eventos e das situações sociais". Na prática jornalística, um enquadramento (framing) é construído através de procedimentos como seleção, exclusão ou ênfase de determinados aspectos e informações, de forma a compor perspectivas gerais através das quais os acontecimentos e situações do dia são dados a conhecer. Trata-se de uma ideia central que organiza a realidade dentro de determinados eixos de apreciação e entendimento, que envolvem inclusive o uso de expressões, estereótipos, sintagmas etc.

Para Colling (2001, p. 14), a mídia não pode expor somente o que ela deseja que saibamos e sim deixarmos cientes de todos os assuntos de agrado ou não da mídia. Em linhas gerais, pautados por uma agenda; a agenda-setting:

Os mais recentes estudos sobre o agendamento têm concluído que a mídia não tem apenas o poder de nos oferecer o leque de assuntos pelos quais iremos nos preocupar e conversar. Além de estabelecer esta agenda interpessoal, os meios de comunicação também teriam o poder de nos dizer como devemos pensar os temas existentes na agenda da mídia. Os pesquisadores têm explicado isso através do conceito do framing, ou enquadramento.

Agenda-setting é considerada mais do que a clássica asserção de que as notícias nos dizem sobre o que pensar. As notícias igualmente nos dizem como pensar acerca disso. A seleção de objetos para a atenção e a seleção dos enquadres pensados acerca destes objetos são o ponto forte do papel do agenda-setting. (MCCOMBS, 1993, p. 62).

\section{Opinião Pública: um conceito que se modifica}

A Opinião Pública está presente na vida das sociedades modernas. Muitas são as formas em que a opinião se manifesta. Mas o que se compreende por "Opinião
Pública"? Inicialmente, na Comunicação Organizacional, conceitua-se Opinião Pública como o resultado de um artifício em Relações Públicas:

No século das Luzes, era concebida como a ex-
pressão de interesse geral e o resultado de dis-
cussões onde, ao contrário do que acontecia
até aí, cada um fazia uso público da sua razão.
Hoje é considerado o produto de políticas das
Relações Públicas pelas quais se pretende aten-
der aos interesses dos diversos públicos, cuja
opinião se torna opinião pública. Esta tem as
características seguintes: não é unânime, não é
necessariamente a opinião da maioria, não cor-
responde à opinião de um qualquer elemento
do público, é uma opinião composta, por cor-
responder a posições várias, e está em formação
contínua. Trata-se de uma ficção estatística ou
de um construtor social, indispensável ao poder
político como: forma de legitimação, instru-
mento do exercício de poder e objeto de mani-
pulação. (OPINIÃO, 2013).

A expressão “Opinião Pública” é parte constituinte da área de teoria política, sendo que conceituar Opinião Pública encontra muitos percalços e limitações. Entretanto, há diversas concepções e chega a ser difícil conceituá-la pela abrangência das ideias. Para o senso comum, a ideia de Opinião Pública, segundo Figueiredo (1996, p. 15) é associada às pesquisas e resultados de opinião: "Nesse sentido, o conceito de Opinião Pública coincidiria com o de pesquisa, que, no mundo moderno, vem desempenhando um papel cada vez mais importante”.

Vale lembrar que todas as conceituações não tratam de algo definitivo. Até porque o tema é amplo, complexo e nele cabem outras definições: "Uma maneira moderna de se conceber a Opinião Pública é a que leva em conta a sua pluralidade. Segundo essa ideia, não existe uma, mas várias maneiras de se identificar os fenômenos de Opinião Pública” (FIGUEIREDO, 1996, p. 20).

A origem da Opinião Pública vem do debate público, onde há o processo de discussão em coletividade, podendo ser implícito ou explícito. Para Rubens Figueiredo (1996, p. 21), o indivíduo não tem condições de tomar uma opinião por si só e sim ele dá importância ao que os outros seres pensam e suas relações, a posição de um formador de opinião e principalmente o que é veiculado e divulgado pelos meios midiáticos ou comunicacionais.

O Dicionário de Política traz uma definição concisa de Opinião Pública:

A Opinião pública é de um duplo sentido: quer no momento de sua formação, uma vez que não é privada e nasce do debate público, quer no seu 
objeto, a coisa pública. Como "opinião", é sempre discutível, muda com o tempo e permite a discordância: na realidade, ela expressa mais juízos de valor do que juízos de fato, próprios da ciência e dos entendidos. Enquanto "pública", isto é, pertencente ao âmbito ou universo político, conviria antes falar de opiniões no plural, já que nesse universo não há espaço apenas para uma verdade política, para uma epistemocracia. A Opinião Pública não coincide com a verdade, precisamente por ser opinião, por ser doxa e não episteme; mas, na medida em que se forma e fortalece no debate, expressa uma atividade racional, crítica e bem informada. (BOBBIO et al, 2010, p. 842)

O norte-americano Walter Lippmann foi um dos pioneiros em estudos e pesquisas sobre a Opinião Pública, e em sua obra clássica Public Opinion argumentou sobre a complexidade do assunto:

\begin{abstract}
Aqueles aspectos do mundo exterior que têm a ver com o comportamento de outros seres humanos, na medida em que o comportamento cruza com o nosso, que é dependente do nosso, ou que nos é interessante, podemos chamar rudemente de opinião pública. As imagens na cabeça destes seres humanos, a imagem de si próprios, dos outros, de suas necessidades, propósitos e relacionamento, são suas opiniões públicas. Aquelas imagens que são feitas por grupos de pessoas, ou por indivíduos agindo em nome dos grupos, é Opinião Pública com letras maiúsculas. (LIPPMANN, 2008, p. 40)
\end{abstract}

\section{A formação da Opinião Pública}

E a formação do fenômeno da Opinião Pública como acontece? Que fatores implicam esse processo? De acordo com Figueiredo (1996, p. 44), a formação ocorre socialmente. Para ele, desde a concepção do indivíduo (nascimento) a opinião já é formada. Surgindo assim as opiniões e atitudes do próprio ser.

Segundo Augras (1980, p. 24), existem fatores que influenciam a formação da opinião são: os fatores psicológicos (nível interpessoal) _ formam atitudes e opiniões, motivações e mecanismos de defesa, sociológicos (nível social) _ terreno em que se constroem as atitudes do grupo e circunstanciais (nível histórico) _ acontecimentos que desencadeiam a conscientização da Opinião Pública.

Para Lage (1998, p. 212) a definição de Opinião Pública:

A opinião pública resulta da interação entre os indivíduos. Logo, não se pode ser explicada por suas ações ou opiniões prévias; na verdade, da troca de informações e de influências, que se acelera diante de fatos novos, resulta concepção da realidade que não existia antes.
Os públicos constituem opinião comum. O consenso dessa opinião resulta em Opinião Pública. Portanto, opiniões individuais não caracterizam o conceito de Opinião Pública. Assim sendo, Lage explica que a Opinião Pública não pode ser formulada por breves opiniões e sim pelas trocas de informações. O conceito de Opinião Pública sugere unidade (a opinião), ao passo que a sua caracterização específica (pública) significa diversidade de indivíduos e das suas opiniões.

A professora da Universidade de São Paulo Sidineia Gomes Freitas, em seu artigo Formação e Desenvolvimento da Opinião Pública, diz que o conceito de Opinião Pública está sempre se modificando. Ela diz:

No século XIX ocorreu a primeira revolução industrial, surgiu a imprensa e as reivindicações deixaram de representar apenas os interesses de um grupo dominante, abrangendo caráter não só político, mas também social e econômico (GOMES, 1984, p. 177-184).

Sabemos que existem diversos fatores que influenciam e determinam a formação da Opinião Pública segundo Monique Augras (1980, p. 24). Gomes faz uma síntese geral desses fatores: "Além da classificação dos grupos, os fatores sociais, os psicológicos, a persuasão e os veículos de comunicação massiva interferem na formação e desenvolvimento da Opinião Pública”.

\section{Ação Penal 470: 0 Caso Mensalão}

Conhecido como um dos maiores esquemas de compra de votos de parlamentares, o escândalo do Mensalão veio à tona no primeiro mandato do governo de Luiz Inácio Lula da Silva (Partido dos Trabalhadores PT). O esquema foi divulgado pelo deputado federal Roberto Jefferson (PTB - RJ), em entrevista ao jornal Folha de S. Paulo, no início de junho de 2005. De acordo com Jefferson, os deputados da base aliada do PT recebiam uma "mesada" de R $\$ 30$ mil para votarem segundo as indicações e preferências do então governo.

Em agosto de 2007, após dois anos, o Supremo Tribunal Federal (STF) acatou a denúncia da Procuradoria-Geral da República e abriu processo contra 40 envolvidos no escândalo do Mensalão. Estão entre os réus: José Dirceu, José Genoino, Anderson Adauto, João Paulo Cunha, Marcos Valério, o delator (acusação) Roberto Jefferson, que responderão por crime de corrupção passiva e ativa, formação de quadrilha, lavagem de dinheiro entre outros.

A Opinião Pública pôde acompanhar todos os 
desdobramentos do caso Mensalão. Mas será que houve condições e espaço para que ela pudesse formar uma opinião sobre tudo que era transmitido pela mídia? Qual foi realmente o papel da mídia durante esse processo? Ela influenciou, contribuiu, condenou, foi omissa nos resultados finais do processo do mensalão?

A fim de responder essas questões, tendo como embasamento os temas Mídia e Opinião Pública, toma-se o estudo de caso do Mensalão como objeto empírico desta pesquisa para assim tentar esclarecer as proposições levantadas no aporte teórico. Passa-se a uma análise de conteúdo temática, a fim de encontrar ressonâncias possíveis com o escopo teórico problematizado por este artigo.

\section{Análise do conteúdo jornalístico}

Claudia Lago, na obra Metodologia de Pesquisa em Jornalismo, explica que, para o autor Earl Babbie (1989), a análise de conteúdo é um dos métodos de estudo de caso e que esse tipo de metodologia é considerado livre de intromissão direta no objeto de estudo. Lago ainda comenta que a análise de conteúdo da mídia propriamente dita teve como um dos fundadores dos estudos de comunicação o americano Harold Laswell, em 1927. Para Laswell (1927), a análise de conteúdo descrevia com objetividade e precisão o que era dito sobre um determinado tema, num determinado lugar num determinado espaço (BABBIE apud LAGO, 2008, p. 124).

A análise de conteúdo, segundo Bardin (2002), é definida por "um conjunto de instrumentos metodológicos cada vez mais sutis em constante aperfeiçoamento, que se aplicam a discursos" (BARDIN, 2002, p. 9). Esse método se aplica ao discurso, ou seja, a tudo que transmite uma mensagem. Pode ser aplicado em entrevistas, matérias de jornais, em imagens de filmes, enfim, qualquer forma de comunicação, seja verbal ou não verbal.

Em Análise de Conteúdo Temático-Categorial: Uma Proposta de Sistematização, Denize Cristina de Oliveira (2008, p. 570) expõe, de forma concisa, que o principal objetivo da análise de conteúdo pode ser sintetizado em manipulação das mensagens, tanto do seu conteúdo quanto da expressão desse conteúdo para colocar em evidência indicadores que permitam inferir sobre uma outra realidade a não ser aquela da mensagem.

Considerado um conceito-chave, a Análise Categorial de Bardin (1977), segundo as exposições de Oliveira, conceitua-se:

Análise Categorial (AC): considera a totalidade do texto na análise, passando-o por um crivo de classificação e de quantificação, segundo a frequência de presença ou ausência de itens de sentido. É um método de gavetas ou de rubricas significativas que permitem a classificação dos elementos de significação constitutivos da mensagem (OLIVEIRA, 2008, p. 3).

A análise de conteúdo é dividida em etapas, mais precisamente em três, conforme define Bardin (2000). São compreendidas em: pré-análise; exploração do material ou codificação; tratamento dos resultados, inferência e interpretação. A pré-analise consiste em estipular um programa de ação, ou seja, organizar documentos de análise, formular as hipóteses e objetivos que embasem ou denotem uma interpretação final. A segunda fase consiste na exploração do material de análise. Nesse momento, o que foi feito na pré-análise é aprofundado, codificado em função de definições previamente estabelecidas. E a última fase é a interpretação dos resultados obtidos. Nessa fase permite-se estabelecer resultados, descobertas através das informações obtidas pela análise.

Para que seja feito a codificação do texto, utilizam-se as unidades de registro que são fundamentais para a realização da análise categorial. A definição dessas unidades é feita a partir do tema da pesquisa, das suas teorias, de estudos anteriores e dos textos que serão analisados. Os autores, Bardin (2002, p. 9) e Weber (1990) definem como unidades de registro determinados elementos a serem analisados. Pode ser uma palavra, frase ou tema. A palavra é a menor unidade de registro nos textos. Podem ser analisadas as palavras-chave, ou as palavras tema, ou a análise de somente uma categoria de palavras (substantivos, adjetivos, advérbios entre outras). O tema corresponde ao assunto do texto. Esse tipo de codificação é o mais comum se tratando da metodologia em análise de conteúdo. O tema como unidade de registro é formado por unidades de texto: sujeito, verbo e objeto. Aquelas frases muito extensas ou complexas podem ser divididas em unidades temáticas.

Weber (1990, p. 21-23) descreve como unidade de registro o parágrafo e o texto inteiro. $\mathrm{O}$ parágrafo é utilizado quando na carência de instrumentos como computadores e limitação de recursos humanos. Essa técnica é eficaz quando faz a seleção de lides em notícias curtas que se utilizam da pirâmide invertida. $\mathrm{O}$ texto inteiro, como unidade de registro, é aconselhado em casos como: manchetes, editoriais, notícias e reportagens curtas. Seguindo as etapas de análise de conteúdo, primeiramente, temos a pré-análise. Nessa etapa será realizada uma seleção de 
temas e palavras relacionadas ao objeto de estudo (Mídia e Opinião Pública). A análise será baseada em temas e palavras (unidades de registro) que apresentarem constantemente repetição nos textos. As unidades de registro avaliadas substancialmente serão substantivos, adjetivos e verbos. O método avaliativo será demonstrado por meio de uma tabela disposta da seguinte forma: a coluna da esquerda conterá as palavras e a direita a frequência em que surge no texto.

Nesse sentido, são necessárias hipóteses para delimitação de nosso objeto de estudo:

- Em relação às unidades de registro no texto (palavras) são recorrentemente notadas nos textos discursivos.

- Essas palavras analisadas exercem no leitor certa influência na formação de opinião desses.

- As palavras analisadas significam no contexto do objeto de pesquisa que a mídia como principal meio de difusão exerce forte poder de convencimento.

- Essas palavras são detentoras de significado e apresentam aos indivíduos a capacidade de formar uma unânime opinião àqueles líderes da Opinião Pública.

O objetivo dessa observação empírica é verificar se essa contínua repetição das unidades de registro (palavras) pode explicar porque a imprensa utiliza essas unidades para impor um conceito predeterminado ao invés de ser mais uma voz na sociedade a compor com os cidadãos na percepção dos fatos. Ou seja, somente o seu decreto sobre o assunto nesse caso o acompanhamento do episódio do Mensalão.

Nessa fase inicial ocorre a escolha do material (corpus), a formulação das suposições e objetivos e a elaboração das hipóteses para ao fim a interpretação dos resultados. A exploração do material ou codificação é feita na segunda fase. Subsequentes a essa etapa, os dados obtidos transformam-se em unidades de análise resultando em uma descrição exata das características pertinentes ao conteúdo do texto.

Dada a importância e abordagem dos temas em discussão: Mídia $x$ Opinião Pública, será analisada a frequência da aparição dessas palavras nas reportagens semanais referentes ao escândalo do Mensalão no período de uma semana entre 20 a 24/08/2007. Foram escolhidos os seguintes veículos: Folha de S.Paulo e O Estado de
S.Paulo pela magnitude e destaque em suas publicações sobre a maior cobertura de um dos mais importantes casos de corrupção já flagrados no Brasil; o Caso Mensalão para contagem, codificação, registro e enumeração desse conteúdo.

\subsection{Jornal Folha de S. Paulo}

É considerado o jornal impresso brasileiro com maior tiragem e circulação. O jornal Folha de S.Paulo, segundo dados do Instituto de Verificador de Circulação (IVC), nos anos de 2006 (denúncia do Mensalão) e 2007 (período analisado do Caso Mensalão - 20 a 24/08/2007), teve respectivamente 309.383 e 302.595 exemplares em circulação por dia. O objetivo do portal é produção de conteúdo via internet seguindo os princípios da Folha de S. Paulo (impresso).

A denúncia do mensalão foi feita em 2006 pelo ex-deputado federal Roberto Jefferson em entrevista à Renata Lo Prete em junho de 2006. Jefferson detalhou todo o esquema e apontou 40 pessoas envolvidas no escândalo de corrupção. A escolha do veículo _ Folha de S.Paulo _ online se deu pela cobertura completa feita pelo portal durante o desenvolvimento do processo do Mensalão. A Folha, inúmeras vezes, teve acesso exclusivo a vários momentos-chave do Caso Mensalão. No site encontra-se a denúncia na íntegra (Inquérito $n^{\circ} 2245$ ).

A Folha de S. Paulo acompanhou e fez uma cobertura assim dividida em partes importantes do escândalo do mensalão, retrancas como: O ESQUEMA, O CAMINHO DO DINHEIRO, DOCUMENTOS, OS JUİZES, AS PENAS, FRASES E QUIZ.

Com a vinheta e design gráfico o julgamento do mensalão, a Folha explorou todo o conteúdo jornalístico sobre o fato. As matérias e reportagens trouxeram uma abordagem explicativa e esclarecedora sobre o caso. Detalhes como linguagem puramente técnica e jurídica dos tribunais e fóruns, análise e visões de colunistas e dia a dia do julgamento foram alguns dos recursos utilizados pelo portal.

Para fazer o recorte e análise do corpus, foram selecionadas 44 matérias, publicadas no período de 20 a 24 de agosto de 2007. A escolha da fase analisada se justifica por ser o momento inicial do julgamento do Caso Mensalão e nessa fase a mídia foi muito incisiva ao pautar a Opinião Pública. A Opinião Pública ansiava pela maior quantidade de informações sobre o caso. E o respectivo momento 
era de expectativa, pois ali se iniciava um dos maiores julgamentos mediado da história. E a partir do método de análise de conteúdo proposto por Laurence Bardin (Edição Revista e Atualizada de 2009) elaborou-se tabelas.

$\mathrm{Na}$ divisão por temas, as palavras foram relacionadas à mídia e opinião e tiveram uma frequência constante (tabela 1).

Tabela 1 - Matérias que abordaram temas que pautassem a Mídia e formaram a Opinião Pública (Quantidade: 44)

\begin{tabular}{|c|c|}
\hline Palavra & Quantidade \\
\hline Imprensa & 1 \\
\hline Poder & 0 \\
\hline Denúncia & 133 \\
\hline Acusações & 13 \\
\hline Escândalo & 33 \\
\hline Crimes & 12 \\
\hline Esquema & 41 \\
\hline Cassados & 0 \\
\hline Justiça & 21 \\
\hline Julgamento & 178 \\
\hline Defesa & 65 \\
\hline Suspeitos & 1 \\
\hline Quadrilha & 7 \\
\hline Lavagem & 48 \\
\hline Dinheiro & 62 \\
\hline Recursos & 2 \\
\hline Envolvimento & 19 \\
\hline Corrupção & 35 \\
\hline
\end{tabular}

Fonte: Martins (2013). A tabela foi elaborada pelo próprio autor.

$\mathrm{Na}$ Tabela 1, constam dezoito palavras que se repetem em quarenta e quatro reportagens do site Folha Online. A expressão que aparece com mais frequência é julgamento com cento e setenta e oito vezes. Na sequência o termo denúncia, cento e trinta e três vezes; $\mathrm{O}$ vocábulo defesa foi repetido sessenta e cinco vezes. A tabela mostrou que a palavra dinheiro foi usada sessenta e duas vezes. As expressões lavagem, esquema, corrupção, escândalo, justiça, envolvimento, acusações e crimes tiveram quarenta e oito, quarenta e um, trinta e cinco, trinta e três, vinte e um, dezenove, treze, e doze aparições respectivamente. As palavras que foram usadas em menor quantidade foram quadrilha com sete vezes, recursos com duas vezes, suspeitos e imprensa uma única vez e os vocábulos poder e cassados não tiveram aparição.

\subsection{Jornal O Estado de S. Paulo}

O jornal mais antigo dos jornais da cidade de São Paulo em circulação é "O Estado de S. Paulo". O portal Estadao.com.br nasceu em março de 2000. O Estado de S. Paulo por meio do site online Estadão realizou a cobertura do Mensalão. O Estadão cobriu o caso desde o começo. O portal trouxe para o seu leitor e ainda podem ser encontrados os seguintes tópicos: SUPREMO X LEGISLATIVO, ENTREVISTA, PLACAR DO MENSALÃO, DENÚNCIA, NOVAS DENÚNCIAS, DEPOIS DO JULGAMENTO, DEFESA, REAÇÃO, AS FRASES DO JULGAMENTO, JUDICIÁRIO, INTERNACIONAL, PENAS, QUEM SÃO, PERSONAGENS, O DIA _ A _ DIA NO STF, O CULPADO, TROCA DE TIROS, ARGUMENTO E DECISÃO, EMBRIÃO DO MENSALÃO entre outros.

A abordagem feita pelo site do Estadão e da cobertura realizada fez-se o recorte das reportagens publicadas entre o período inicial do julgamento do mensalão, de 20 a 24 de agosto de 2007. Baseando-se em Bardin e seu método de análise de conteúdo temático-categorial, realiza a codificação das unidades de registro, procedimento anteriormente adotado, com a divisão por temas, as palavras foram relacionadas aos objetos de pesquisa: mídia e opinião e tiveram a seguinte frequência nas matérias selecionadas.

Como já ocorrido com o jornal Folha Online, no estadão.com.br o mesmo procedimento será adotado, com a divisão por temas, as palavras foram relacionadas aos objetos de pesquisa: mídia e opinião e tiveram a seguinte frequência (tabela 2).

Tabela 2 - Matérias que abordaram temas que pautassem a Mídia e formaram a Opinião Pública (Quantidade: 21)

\begin{tabular}{|c|c|}
\hline Palavra & Quantidade \\
\hline Imprensa & 1 \\
\hline Poder & 4 \\
\hline Denúncia & 100 \\
\hline Acusações & 8 \\
\hline Escândalo & 8 \\
\hline Crimes & 9 \\
\hline Esquema & 33 \\
\hline Cassados & 14 \\
\hline Justiça & 11 \\
\hline Julgamento & 70 \\
\hline
\end{tabular}




\begin{tabular}{|c|c|}
\hline Defesa & 28 \\
\hline Suspeitos & 3 \\
\hline Quadrilha & 50 \\
\hline Lavagem & 74 \\
\hline Dinheiro & 85 \\
\hline Recursos & 5 \\
\hline Envolvimento & 9 \\
\hline Corrupção & 65 \\
\hline \multicolumn{2}{|c|}{ Fonte: Martins (2013). } \\
\hline
\end{tabular}

Na Tabela 2, constam dezoito palavras que repetem em vinte e uma notícias do site Estadão.com.br. A expressão que aparece com mais frequência é denúncia com cem vezes. Na sequência o termo dinheiro, oitenta e cinco vezes; $\mathrm{O}$ vocábulo lavagem foi repetido setenta e quatro vezes. A tabela mostrou que a palavra julgamento foi usada setenta vezes e corrupção sessenta e cinco vezes. As expressões quadrilha, esquema, defesa, cassados e justiça tiveram cinquenta, trinta e três, vinte e oito, quatorze e onze aparições respectivamente. Crimes e envolvimento foram repetidos nove vezes cada. As seguintes expressões: acusações e escândalo foram usadas oito vezes. As palavras que foram usadas em menor quantidade foram recursos com cinco vezes, poder com quatro vezes, suspeitos três vezes e imprensa uma aparição.

O conceito de Opinião Pública, em seu sentido amplo como ideia de público e de grupo, permite fazer a essa observação empírica uma interpretação valorativa do significado dos fatos. Sobre esse estudo da Opinião Pública, afirma-se a existência da opinião como expressão de determinados grupos, utilizando-se a mídia para tornar públicas essas opiniões.A opinião tem sua origem nos grupos e esses grupos quando organizam em torno dos temas de discussão e de interesse público como o Caso Mensalão.. Desse modo, a Opinião Pública é “entusiasmada" pelos veículos de comunicação de massa e procura formar um consenso.

São diferentes públicos (grupos de interesse, pessoas interessadas e espectadores) que munidos de opiniões e até mesmo de informações diferenciadas sobre um mesmo fato que, muitas vezes, não chega a essa concordância e que disseminam as suas opiniões pelos veículos de comunicação massiva. Aqueles que conseguem tornar pública uma dada opinião se sobressaem. Ou seja, a Opinião Pública, em linhas gerais é a opinião de um determinado grupo, mas não necessariamente a opinião da maioria, voltada a interesses particulares e privados. Por essa razão há a relação entre a Mídia versus Opinião Pública em que a mídia se mobiliza, partindo desse universo indefinido constituído de interesses públicos e pela opinião privada, que se manifesta como pública. Ressalta-se que a opinião está em contínuo processo de formação e em direção a um consenso completo, sem nunca alcançá-lo.

\section{Resultados e discussão}

Para a análise quantitativa, foram coletadas 1.248 palavras (verbos, substantivos e adjetivos) e verificou-se a análise de frequência das unidades de registro. Utilizando-se a análise de conteúdo como método de pesquisa em estudo de caso e na obtenção dos resultados, pode-se inferir que, no Caso Mensalão, a parte analisada (período inicial do julgamento) proporcionou assunto para debates e formações de opinião além do senso comum.

A mídia instruiu, apresentou e traduziu todo o processo do Caso Mensalão de forma que a Opinião Pública pudesse acompanhar diariamente o andamento desse processo, as discussões e divagações que se resumiam as incansáveis sessões do julgamento. De um lado, havia uma parcela expressiva da população que ansiava por respostas imediatas e punitivas na expectativa de condenação dos réus e de outro, o STF fazia o que lhe cabia julgando o caso.

A mídia não apenas portou a informação nesse caso, como também foi formadora da Opinião Pública. O que nutre a mídia são justamente essas inconstâncias da Opinião Pública em que opiniões privadas, por meio dos media, tornam-se públicas. A mídia teve um papel essencial, pois fazia a ponte entre os anseios da sociedade aos desdobramentos do julgamento e a relação entre o Supremo, Mensalão e Opinião Pública.

Por ser um fenômeno concreto, passível de observação, estudo e avaliação, Augras (1980) explica que a expressão da Opinião Pública está ligada a uma atividade política. Que são as deliberações dos cidadãos da polis grega que aconteciam em locais denominados de ágora (espécies de mercados ou praças). Nesses lugares, os gregos tomavam suas decisões pautadas pelo governo em Atenas. No final do Século V, a. C surge uma classe de homens políticos, os chamados demagogos. Esses tinham o poder de conduzir o povo e orientá-los conforme achavam que deveriam. Pareciam ser líderes de opinião.

Quando Lippmann (2008) examina os meios de 
comunicação de massa e o estudo da Opinião Pública, ele indica que a grande maioria das pessoas não leem as notícias, mas sim o que é indicado para elas. Isso é explicado pelo fato das mesmas pessoas estarem expostas à sugestão aconselhando o que devem fazer, que decisão tomar etc.

Em relação aos efeitos dos meios de comunicação de massas na formação da Opinião Pública, o estudo da agenda-setting que simplifica e seleciona os temas a serem pautados pela mídia no Caso Mensalão constatou que a imprensa midiática, no caso os jornais impressos analisados exerceram, influenciaram e determinaram o grau de atenção que o leitor ou telespectador dedicou a temas assim expostos à atenção e interesses públicos e coletivos, como foi o Caso Mensalão.

Dada a análise desse caso de corrupção, um fato com essa conjectura, uma forte relação entre a mídia, a política e a Opinião Pública provocou discussão. Falar da influência da mídia e seus efeitos e o papel desempenhado pelo jornalismo requer um questionamento sobre a função jornalística e os limites da informação.

Do ponto de vista da análise de conteúdo, verifica-se que, em relação à reflexão sobre a mídia e sua influência sobre a formação da Opinião Pública, com base no objeto de estudo de caso, o escândalo do mensalão, é válido dizer que a Opinião Pública formou-se como resultado de ondas de entendimento e camadas interpretativas ao longo do evento do julgamento do mensalão e continua a fazê-lo. A mídia e seus meios de comunicação, representados no corpus deste estudo pelos jornais diários Folha de S. Paulo e O Estado de S. Paulo, não determinam, mas compõe esse entendimento. É evidente que a Opinião Pública é constituída de diversas opiniões existentes no público e está em contínuo processo de formação em busca de um consenso lúcido e arrazoado.

Ao estabelecer os indicadores (presença/ frequência e/ou ausência) na codificação dos textos e mera contagem das palavras, pode-se perceber que algumas unidades tiveram um nível de mensuração mais elevado em relação a outras palavras. $\mathrm{Na}$ análise pode-se constatar que a palavra mais citada no jornal Folha de São Paulo foi julgamento, apareceu 178 vezes nas quarenta e quatro matérias que abordavam o tema: Julgamento do Mensalão, todas voltadas para o contexto do caso de corrupção. A palavra mais citada nas matérias do site O Estado de $S$. Paulo foi denúncia repetida 100 vezes.

Um caso como esse, do maior escândalo de corrupção do Brasil, ganhou destaque nas redes sociais como um dos assuntos mais comentados entre os seguidores do Twitter. A repercussão nos noticiários, impressos e demais veículos de massa pautou a extensão e proporção dos diversos leads noticiados.Jornalistas, psicólogos, sociólogos, políticos, historiadores, estatísticos, cientistas sociais e políticos, leitores e telespectadores puderam acompanhar todos os passos no processo do mensalão e formaram a Opinião Pública. O papel da imprensa inevitavelmente é informar, mas necessariamente ela não forma ou deforma uma decisão do Supremo. Nesse caso, a Opinião Pública é responsável por julgar o STF. As pessoas criaram uma expectativa muito grande em torno do caso e a mídia apresentou um bombardeio de informações. Pode-se notar que, apesar de tudo, o Supremo não se deixa influenciar pela pressão popular, mas a mídia e Opinião Pública pautaram o Supremo. Que fique claro que não são elas que ditam as ações do Supremo Tribunal Federal, mas que podem oferecer opacidade às discussões se mantidas no horizonte das questões ali consideradas. A influência da imprensa e a manifestação da Opinião Pública formada pelas redes sociais dão audiência a essas agendas sociais.

Com esse cenário, a Opinião Pública e a mídia puderam se informar, avaliar e criticar cada passo dado pelos autores e envolvidos do Caso Mensalão. Vale lembrar que os leitores contemporâneos usam a internet para buscarem informação e ao mesmo tempo produzirem informação, corroborando a ideia de que a Opinião Pública é formada por fragmentos de opiniões e não uma opinião individualizada que forma a Opinião Pública. Portanto, segundo Augras (1980), ela é fundamentada pelo sistema social de um país, uma comunidade e pelos veículos de comunicação de massa (mídia) capazes de mudar os pensamentos, ações, concepções e principalmente as opiniões.

A sociologia crítica atual aponta como fatores do declínio da Opinião Pública a inexistência de lugares que facilitariam a formação por meio do diálogo: ao invés de salas de reunião, os espaços que proporcionariam a formação da Opinião Pública seriam: a televisão, jornais como empresas de especulação, partidos e associações dirigidos por oligarquias. Do mesmo modo que no Estado contemporâneo não há distinção entre Estado e sociedade civil, pois ambas se compenetraram, dando lugar a uma classe, a Elite que manipula facilmente a Opinião Pública. É preciso que as organizações que controlam os meios de comunicação de massa passem a criar espaços abertos para diálogos e não de manipulação, como acon- 
tece por vezes na publicidade em que há essa relação entre o consumo e o consumidor.

A existência das novas tecnologias nos meios de comunicação de massa ofuscou a imagem da Opinião Pública. Entretanto, aonde ainda há liberdade de expressão, pluralidade de ideias e de informação pode-se formar a Opinião Pública.

\section{Considerações finais}

O estudo de caso, realizado neste estudo, conseguiu resolver os problemas de pesquisa propostos no início do trabalho. A realização de um estudo de caso sobre a função exercida pelo jornalismo, por meio dos jornais Folha de S. Paulo e Estado de S. Paulo, tratou a questão da Opinião Pública por meio de referenciais teóricos e de diferentes visões sobre a questão da Mídia versus Opinião Pública. Compreender a mídia e seu papel no processo de formação da opinião pública, analisar a existência ou não da opinião pública e a demonstração empírica dos processos de construção da opinião pública foram os objetivos alcançados.

A metodologia utilizada foi suficiente para realizar os procedimentos bibliográficos precisos, a bibliografia correspondeu às expectativas e, após constante leitura, análises, comparativos e sínteses de diferentes autores a respeito do tema, o problema de pesquisa atingiu o seu objetivo principal, de estudar a influência da mídia e o seu papel na formação da Opinião Pública.

Considerando-se o estudo de caso para demonstração empírica dos processos de construção da Opinião Pública, a análise do corpus, a exploração desse material (codificação) e dos resultados obtidos pode-se concluir que a mídia contribuiu para a formação e desenvolvimento da Opinião Pública, pautando-a como ela fez no estudo de caso: o Mensalão, entretanto a mídia não teve o papel de manipular as opiniões de leitores e telespectadores conforme hipoteticamente levantado no início do artigo. E, para responder a indagação, se a Opinião Pública ainda existe, ou a mídia tornou-se a Opinião Pública? Fica claro que a Opinião Pública existe e que ela está constantemente em busca de um consenso, além de ela ser móvel e os meios de comunicação de massa a subsidiam para os assuntos de interesses públicos e particulares em pauta na sociedade como o do Caso Mensalão.

A relação entre a Opinião Pública e o Supremo, no Caso Mensalão comprova que, por ser livre, facilmen- te modificada e moldável, a Opinião Pública foi formada pelos emaranhados dos acontecimentos. Houve, sim, uma separação entre o judiciário e a Opinião Pública que se desfez à medida que os fatos eram apresentados à população. A Suprema Corte foi questionada pela Opinião Pública que por sua vez fez com que o STF se questionasse como estavam sendo vistos perante a sociedade. A despeito da visão em descrédito que a grande maioria possui em relação à justiça brasileira, pode-se dizer que aconteceu esse rompimento entre a sociedade e o Supremo Tribunal Federal.

O intuito dessa atualização do tema Opinião Pública é promover uma reflexão ativa sobre os acontecimentos históricos e políticos mais recentes da sociedade brasileira. A esses aspectos e pela inesgotável fonte de pesquisa, os temas mídia e Opinião Pública não cessarão aqui neste artigo. Ainda há muito a se dizer sobre o assunto. Aos futuros pesquisadores, segue fonte de inspiração para as próximas páginas desse ou de outros trabalhos acadêmicos dando continuidade a esse amplo e inquietante tema.

\section{Referências}

AUGRAS, M. À procura do conceito de opinião pública. In: AUGRAS, Monique. A teoria. Rio de janeiro: Vozes, 1980. p. 11-24.

BOBBIO, N. et al. Dicionário de política. 13. ed. Brasília: UnB, 2010.

CHRISTOFOLETTI, R. Vitrine e vidraça: crítica de mídia e qualidade no jornalismo. In: CHRISTOFOLETTI, Rogerio. O conceito de enquadramento e sua contribuição à crítica de mídia. Covilhã: LabCom Books, 2010. p. 54.

COLLING, L; Agenda-setting e framing: reafirmando os efeitos limitados. Revista Famecos, Porto Alegre, n. 14, p. 7, Quadrimestral, 2001.

ESTEVES, J. P. Opinião Pública. In: DICIONÁRIO de Filosofia Moral e Política. Instituto de Filosofia da Linguagem. Disponível em: <www.ifl.pt/private/admin/ficheiros/uploads/bb18377ce1ceb84eec946e26baffeea9.pdf > . Acesso em: 24 out. 2013.

FALCAO, J. Mensalão: diário de um julgamento: supremo, mídia e opinião pública. Rio de Janeiro: Elsevier, 2013.

FIGUEIREDO, R. O que é opinião pública. São Paulo: Brasiliense, 1996. 
GOMES, S. Formação e desenvolvimento da opinião pública. Revista Comunicarte, Campinas, v. 2, n. 4, p. 177184, jun./dez. 1984. Disponível em: <http://www.portal-rp.com.br/bibliotecavirtual/opiniaopublica/0017.htm>. Acesso em: 10 set. 2013.

LAGE, N. Controle da opinião pública: um ensaio sobre a verdade conveniente. Petrópolis: Vozes, 1998.

LIPPMANN, W. Opinião pública. Rio de janeiro: Vozes: 2008.

MARTINS, R. A mídia nos representa? Carta Capital, São Paulo, p. 30-31, 25 set. 2013.

OLICSHEVIS, G. Mídia e opinião pública. Revista Vernáculo, Paraná, n. 17/18, p. 2006.

OliveirA, D. C. de. Análise de Conteúdo Temático-Categorial: uma proposta de sistematização. Rev. Enferm. UERJ, Rio de Janeiro, v. 16, n. 4, p. 569-76, out./dez. 2008. Disponível em: <http://www.facenf.uerj.br/v16n4/ v16n4a19.pdf $>$. Acesso em: 24 out. 2013.

OPINIÃO Pública (comunicação organizacional). Disponível em: <http://www.infopedia.pt/\$opiniao-publica-(comunicacao-organizacional); jsessionid=bxVL2SINE-
QNcQGxomuCexQ_>. Acesso em: 15 ago. 2013.

RAYMUNDO, F. A. Mídia: o poder e os seus caminhos. Disponível em: <http://franciscoaraymundo.blogspot. com.br/2010_03_01_archive.html>. Acesso em: 09 jun. 2013.

SENA, N. M. Espaço público, opinião e democracia: conceito de opinião pública e delimitação teórica. Estudos em Comunicação, Curitiba, n. 1, p. 270-304 abr. 2007.

SILVERSTONE, R. Por que estudar a mídia? São Paulo: Loyola, 2002.

VESTENA, C. L. B. O papel da mídia na formação da opinião pública: a contribuição de Bourdieu. Disponível em: $<$ http://revistas.unicentro.br/index.php/guaiaraca/article/viewFile/1144/1089>. Acesso em: 16 jul. 2013. 